\section{ORCID}

Nu Ri Jang, https://orcid.org/0000-0001-7182-964X

Min Kyoung Kim, https://orcid.org/0000-0003-0088-0995

Dong Hoon Shin, https://orcid.org/0000-0003-3130-3699

Mi Jin Gu, https://orcid.org/0000-0002-8350-3038

\section{REFERENCES}

1. Kempf W, Keller K, John H, Dommann-Scherrer C. Benign atypical intravascular CD30 + T-cell proliferation: a recently described reactive lymphoproliferative process and simulator of intravascular lymphoma: report of a case associated with lichen sclerosus and review of the literature. Am J Clin Pathol 2014;142:694-699.
2. Riveiro-Falkenbach E, Fernández-Figueras MT, RodríguezPeralto JL. Benign atypical intravascular CD30(+) T-cell proliferation: a reactive condition mimicking intravascular lymphoma. Am J Dermatopathol 2013;35:143-150.

3. Samols MA, Su A, Ra S, Cappel MA, Louissant A Jr, Knudson RA, et al. Intralymphatic cutaneous anaplastic large cell lymphoma/lymphomatoid papulosis: expanding the spectrum of CD30-positive lymphoproliferative disorders. Am J Surg Pathol 2014;38:1203-1211.

4. Nguyen $\mathrm{GH}$, Yassin AH, Magro CM. Unusual variants of intravascular malignant hematopoietic neoplasms: a report of 4 cases and review of the literature. Am J Dermatopathol 2015;37:360-367.

5. Calamaro P, Cerroni L. Intralymphatic proliferation of T-cell lymphoid blasts in the setting of hidradenitis suppurativa. Am J Dermatopathol 2016;38:536-540.

\title{
Fibroma of Tendon Sheath Mimicking a Corn - a Rare Hand Tumor
}

\author{
Hee Jae Park, Seung Pil Ham, Cheong Ha Woo, Mira Choi, Hai-Jin Park \\ Department of Dermatology, Ilsan Paik Hospital, Inje University College of Medicine, Goyang, Korea
}

\section{Dear Editor:}

Fibroma of tendon sheath (FTS) is an uncommon soft tissue neoplasm belonging to the benign fibroblastic/myofibroblastic tumor group. It is manifested as an asymptomatic, firm, and well-demarcated nodule that grows slowly. FTS has a predilection to adhere to the tendon or tendon sheath of digits and palms, especially on the flexor surface ${ }^{1}$.

A 21-year-old man visited our department with a 2-month history of a solid mass on the volar aspect of his left thumb (Fig. 1). Physical examination revealed a hard hy- perkeratotic papule, smaller than $1 \mathrm{~cm}$. He reported mild tenderness without limitation in the range of motion. There was no history of trauma, but the lesion was trimmed at the local clinic due to suspicion of corn. To confirm a diagnosis, an incisional biopsy was performed. The specimen showed a well-circumscribed tumor in the deep dermis comprised of hyalinized collagenous fibers with haphazardly arrayed spindle-shaped cells and slit-like vascular spaces. The cells were immunoreactive for smooth muscle actin (SMA) and the fibrotic regions appeared blue in Masson's trichrome staining (Fig. 2). Based on the clin-

\footnotetext{
Received January 12, 2018, Revised February 8, 2018, Accepted for publication February 12, 2018
}

Corresponding author: Hai-Jin Park, Department of Dermatology, Ilsan Paik Hospital, Inje University College of Medicine, 170 Juhwa-ro, Ilsanseo-gu, Goyang 10380, Korea. Tel: 82-31-910-7224, Fax: 82-31-910-7227, E-mail: stratum@paik.ac.kr ORCID: https://orcid.org/0000-0002-9274-9371

This is an Open Access article distributed under the terms of the Creative Commons Attribution Non-Commercial License (http://creativecommons.org/ licenses/by-nc/4.0) which permits unrestricted non-commercial use, distribution, and reproduction in any medium, provided the original work is properly cited.

Copyright (C) The Korean Dermatological Association and The Korean Society for Investigative Dermatology 
ical and histopathologic findings, a diagnosis of FTS was established. The patient was requested to come in for further evaluation, but lost to follow-up.

FTS, also known as tenosynovial fibroma, accounts for approximately $3 \%$ of the incidence of all hand tumors ${ }^{2}$. It occurs 2.5 times more frequently on the right hand as well as on the volar surface and $10 \%$ of which is related to trauma, supporting a reactive fibrosing process ${ }^{1}$. It also has been described as a fibrotic neoplasm due to its chromo-

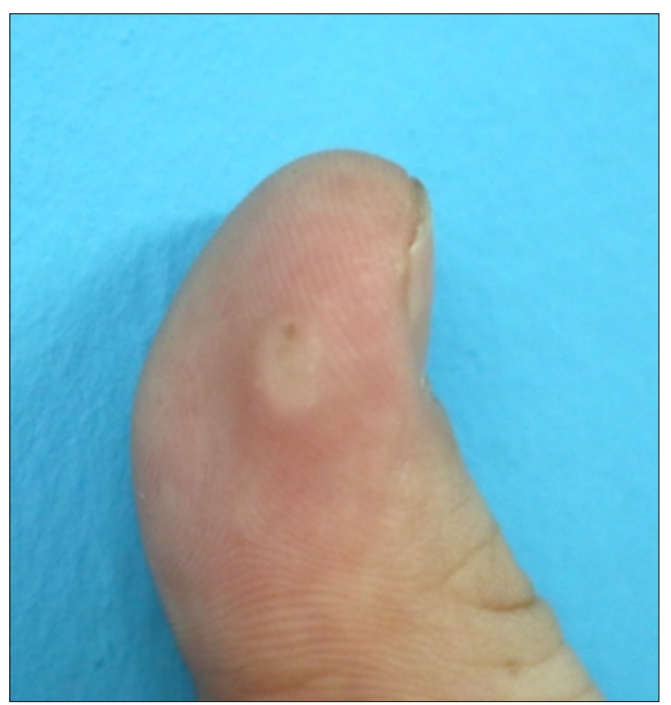

Fig. 1. Solitary hyperkeratotic non-movable papule on the flexor surface of the distal phalanx of the left thumb. We received the patient's consent form about publishing all photographic materials. somal 2;11 translocation abnormality ${ }^{3}$. However, the pathogenesis regarding the origin has not been precisely established.

Considering the clinical and histological features, the differential diagnosis should include nodular fasciitis, giant cell tumor of tendon sheath (GCTTS), and desmoplastic fibroblastoma (DFB). Histopathologically, FTS is a well-lobulated encapsulated tumor, which consists of fibroblast-like spindle cells and numerous cleft-like vascular channels embedded in a dense hyalinized fibrous stroma. Composed of a predominantly paucicellular component, it is admixed with some hypercellular areas arranged in a storiform pattern. The matrix is stained blue with Masson's trichrome staining suggesting collagen alignment, and the tumor cells express myofibroblastic markers such as SMA and vimentin. GCTTS shows osteoclast-like multinucleated giant cells and stains positive for histiocytic determinants like CD68 ${ }^{4}$. Nodular fasciitis presents with a tissue-culture like growth pattern of randomly configured myofibroblasts. DFB and FTS show an identical cytogenetic aberration and similar histopathologic findings, so they are considered as parts of a morphological spectrum of a single entity. However, DFB commonly involves skeletal muscle or subcutaneous tissue of the extremities and trunk, and the vascular structure is not striking ${ }^{5}$.

Because a tumor firmly adhering to the tendon or tendon sheath shows a high recurrence rate, careful surgical excision is necessary for complete removal ${ }^{1}$. Herein, we report a rare case of FTS mimicking a corn or wart on the finger; therefore it is important to differentiate clinically

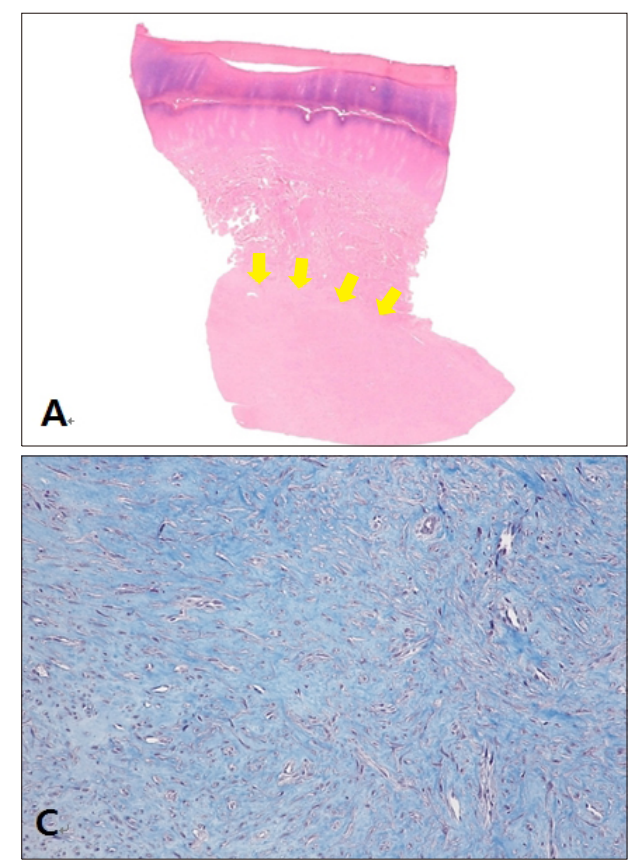

Fig. 2. (A) Homogenous and wellcircumscribed fibrous lesion in the deep dermis (yellow arrows) (H\&E, scanning view). (B) Hyalinized collagen-like stroma with haphazardly arranged spindle-shaped cells and randomly spaced cleft-like vascular channels (red arrows) (H\&E, $\times 100$ ). (C) Hyalinized collagenous stroma stained blue with Masson's trichrome stain $(\times 100)$. (D) The cells are stained diffusely positive for smooth muscle actin $(\times 200)$. 
Brief Report

and pathologically from other tumors.

\section{CONFLICT OF INTEREST}

The authors have nothing to disclose.

\section{ORCID}

Hee Jae Park, https://orcid.org/0000-0002-3998-9042

Seung Pil Ham, https://orcid.org/0000-0002-4472-2043

Cheong Ha Woo, https://orcid.org/0000-0001-5538-7933

Mira Choi, https://orcid.org/0000-0003-2464-9675

Hai-Jin Park, https://orcid.org/0000-0002-9274-9371

\section{REFERENCES}

1. Chung EB, Enzinger FM. Fibroma of tendon sheath. Cancer 1979;44:1945-1954.

2. Millon SJ, Bush DC, Garbes AD. Fibroma of tendon sheath in the hand. J Hand Surg Am 1994;19:788-793.

3. Dal Cin P, Sciot R, De Smet L, Van den Berghe $H$. Translocation $2 ; 11$ in a fibroma of tendon sheath. Histopathology 1998;32:433-5.

4. Maluf HM, DeYoung BR, Swanson PE, Wick MR. Fibroma and giant cell tumor of tendon sheath: a comparative histological and immunohistological study. Mod Pathol 1995;8:155-159.

5. Gong LH, Liu WF, Ding Y, Geng YH, Sun XQ, Huang XY. Diagnosis and differential diagnosis of desmoplastic fibroblastoma by clinical, radiological, and histopathological analyses. Chin Med J (Engl) 2018;131:32-36.

\title{
A Case of Congenital Ectopic Nail Located on the Left 5 th Toe
}

\author{
Jun Hong Park, Jun Young Kim, Weon Ju Lee \\ Department of Dermatology, School of Medicine, Kyungpook National University, Kyungpook National University Hospital, Daegu, Korea
}

\section{Dear Editor:}

Ectopic nail is a condition involving the development of an additional and independent nail in an abnormal site. Few cases of congenital ectopic nail have been reported in the worldwide dermatological literature ${ }^{1}$. In Korea, a case of congenital ectopic nail was reported by Lew et al. ${ }^{2}$. In addition, a report on a Korean patient with posttraumatic ectopic nail was published in the Journal of Pediatric Dermatology in $2016^{3}$.
Herein, we describe a 62-year-old female patient with a congenital ectopic nail on the left 5th toe (Fig. 1A) that developed at birth. The nail had been felt tender for the last 2 years. There were no abnormal laboratory findings. Moreover, there were no abnormal bony deformities on radiological examination (Fig. 1B). She underwent surgery for removal of the congenital ectopic nail (Fig. 1A). Histopathologically, the congenital ectopic nail showed prominent hyperkeratosis (Fig. 2A). The expression of $\beta$ -

Received October 16, 2017, Revised February 3, 2018, Accepted for publication February 25, 2018

Corresponding author: Weon Ju Lee, Department of Dermatology, Kyungpook National University Hospital, 130 Dongdeok-ro, Jung-gu, Daegu 41944, Korea. Tel: 82-53-420-5838, Fax: 82-53-426-0770, E-mail: weonju@knu.ac.kr ORCID: https://orcid.org/0000-0001-5708-1305

This is an Open Access article distributed under the terms of the Creative Commons Attribution Non-Commercial License (http://creativecommons.org/ licenses/by-nc/4.0) which permits unrestricted non-commercial use, distribution, and reproduction in any medium, provided the original work is properly cited.

Copyright (C) The Korean Dermatological Association and The Korean Society for Investigative Dermatology 